\title{
Effects of Computer-Based Simulations on Senior Secondary School Students' Performance in Physics Practical, Osun State, Nigeria
}

\author{
Oyetola Oyeniran $^{1} \quad$ Temitope Adetokunbo Oteyola ${ }^{1,2^{*}} \quad$ Emmanuel Olajide Awopetu ${ }^{1,2,3}$ \\ Opeoluwa Morenike Afolabi ${ }^{1,2,3,4}$ \\ 1. Department of Educational Technology and Library Studies, Obafemi Awolowo University, \\ P.M.B. 13, Ile Ife, Osun State Nigeria \\ 2. Department of Educational Technology and Library Studies, Obafemi Awolowo University, \\ P.M.B. 13, Ile Ife, Osun State, Nigeria \\ 3. Department of Arts and social Science Education, Obafemi Awolowo University, \\ P.M.B. 13, Ile Ife, Osun State, Nigeria \\ 4. Centre for Distance Learning, Obafemi Awolowo University Ile Ife, Osun State, Nigeria
}

\begin{abstract}
The study determined the effects of Computer-based Simulations (CBSs) on the academic performance of senior secondary school students' in Physics Practical. It also determined the influence of sex on the effects of the simulations on students' academic performance in Physics practical. Pretest - posttest control group quasi experimental design was adopted for the study. Two intact classes of students of Physics in senior secondary II (SS II) were purposively selected for the study. The classes were randomly assigned into experimental and Control group. Physics Practical Performance Test (PPPT) was used for data gathering. Data collected were analysed using ANCOVA and 2 - way ANOVA. Results showed that CBSs had significant effects on students' academic performance in Physics practical $\left(\mathrm{F}_{(1,74)}=5.51 ; \mathrm{p}<0.05\right)$. Sex has no significant influence on the effect of CBSs on students' academic performance in Physics practical $\left(\mathrm{F}_{(1,74)}=0.05 ; \mathrm{p}>0.05\right)$. It is therefore concluded that CBSs can be employed in the teaching of Physics practical at the senior secondary schools.
\end{abstract}

Keywords: Computer-based simulations, Learning Outcomes, Physics practical, Senior secondary II (SSII).

DOI: $10.7176 / \mathrm{JEP} / 12-21-06$

Publication date:July $31^{\text {st }} 2021$

\section{Introduction}

Physics occupies an exceptional position among other science disciplines due to the numerous applications of its concepts to the development and improvement of man and his environment. Oteyola (2015) asserts that Physics serves as the backbone of any scientific invention and the source of relevant ideas aimed at providing solutions to numerous challenges facing humanity. The fact remains that no country can occupy any significant position or be ranked among developed nations of the world without the intervention of Physics.

In Nigeria, Physics is made a compulsory subject for students in science department at the senior secondary schools. The implication of this is that it is impossible for a student to pursue any science and engineering related course at the tertiary level without at least a credit pass in Physics in secondary school certificate examination. The Nigerian Senior Secondary School Physics curriculum was designed to achieve the following objectives:

(i) provision of basic literacy in Physics for functional living in the society;

(ii) acquisition of basic concepts and principles of Physics as a preparation for further studies;

(iii) acquisition of essential scientific skills and attitudes as preparation for the technological application of Physics; and

(iv) stimulation and enhancement of creativity (Federal Ministry of Education, 2014).Physics is therefore an integral foundation for science courses at higher institutions of learning.

Moreover, it is worthy to note that Physics Practical is an integral aspect of Physics which will help in achieving objectives (ii) and (iii) of secondary school Physics curriculum. The teaching of Physics in secondary schools in Nigeria had been theoretical with students having little access to practical work (Oteyola, 2015, Omosewo, 2009, Babalola, 2012, Oteyola, Ojediran \& Adeyanju, 2016). Jegede and Taylor (1998), Okebukola (2004), Tsui and Treagust (2004) opined that adopting activity-based teaching methods such as experimentation will arouse learners' full participation and at the same time activate learners' active roles of applying scientific concepts during teaching and learning. Practical-based activities in Physics according to Azar and Şengülec (2011), Al-Abri (2010) Kollöffel and de Jong (2013) promote students' understanding of the concept being taught, activate knowledge construction, enhance positive attitude in students and also arouse retention of Physics concepts. Unfortunately, Physics practical classes that will impart in the students applications of the concepts taught in the classroom are not being properly handled as reported in WAEC Chief Examiners' Reports of 2010, 2011 and 2012.

Taibu, Mataka and Shekoyan (2021) citing Volkmann and Abel (2003) stated that traditional Physics lab 
follows a cookbook approach which are organized around five pillar steps: purpose, procedure, data, analysis and conclusion. This approach according to Taibu et al (2021) do not properly address the last three stages of Bloom's cognitive taxonomy which are analysis, evaluation and synthesis. These three stages of the Bloom's taxonomy provide the requisite skills needed in technological transformation of any nation.

The traditional Physics lab method of laboratory activities is predominant among teachers in Osun state. Inquiry based activities are not employed in Physics practical activities in secondary schools in Osun State, Nigeria as a result of limited apparatus and time constraints. As identified by Taibu et al (2021), challenges of apparatus due to cost and space is also prevalent in the secondary schools. As a result of this development, secondary schools across the state only engage in Physics practical exercise for students to pass the senior school certificate examination conducted by West Africa Examination Council (WAEC) or National Examination Council (NECO). The students are barely introduced to practical classes few weeks to the Senior School Certificate Examinations (SSCE). This is usually done after the instructions on the materials that would be required for conducting the practical examinations had been sent by the examination bodies. This have negative impact on the scientific skills of students that are to be enrolled at higher institutions of learning in Nigeria and thus achieving the objectives of Physics education is made elusive.

Physics practical at the senior secondary schools in Nigeria is bedevil with some challenges which include shortage of professionally trained Physics teachers coupled with inadequate periods allocated to the subject on the school time table (Okebukola, 1997; Bajah, 1998; Ogunleye, 2000; Umeh, 2002; Jegede \& Adedayo, 2013; Oteyola 2010; and Oteyola, 2015;), inadequate standard and under-equipped Physics laboratories (Adegoke \& Chukwunenye, 2013) and adoption of crude pedagogical approach of chalk and talk (Abungu, Okere \& Wachanga, 2014).

The persistence of these challenges has led to poor attitude of students towards the subject, poor scientific skills, general misconception of concepts in Physics and poor academic performance in Senior Secondary School Certificate examinations among others (Okebukola, 1997; Ogunleye, 2000; Ogunleye, 2001; Umeh, 2002; NERDC, 2005 Bunkure, 2008; Oteyola 2010, Atadoga \& Lapkini, 2012; Oteyola, 2015). It is therefore pertinent that other methods of teaching Physics be experimented so as to find a way of improving and facilitating students' performance in the subject. This will help in ensuring that the objectives of Physics as stated in the secondary school Physics curriculum is achieved. It will help in improving the scientific attitude and process skills of the students. This will eventually aid technological development in the State and Nigeria at large.

Computer-based simulations has been effective in simulating practical activities globally. Therefore, introduction of computer-based simulations to enhance students' access to Physics practical activities in the State should be a welcome idea. It is also imperative that before informed decision will be made by the stakeholders, it is necessary that research be conducted to ascertain the effectiveness of this innovation.

\subsection{Literature Review}

Studies abound on the applicability and effectiveness of the computer-based simulations modes for instructional delivery in other clime. Kozielska and Kedzierski (2007) summarized that computer simulations are virtual replications of instructional scenarios that offer students the opportunity to learn about phenomena in conditions where it is tough to carry out due to time challenges, safety concerns, or absence of adequate instruments and thus extending the space between the physical and theoretical concepts. To get rid of the negative impact of poor equipped laboratory on students' academic performance in Physics, Azar and Şengülec (2011) suggested that Computer simulations of Physics experiments could be effectively adopted because students are permitted to have direct contact with the replicated real laboratory setup virtually. As verified by Chukwunenye (2011), computer simulations like Physics Education Technology (Ph.ET) Interactive Simulations, Interactive Physics, Edison 4.0, Crocodile Physics, and Virtual Labs, were designed to reproduce Physics practical that were performed in a virtual form on the computer for students to explore. Taibu et al (2021) also reported the application of Ph.ET in improving scientific skills and attitude of community college students in North-Eastern urban college in the United State of America (USA).

Hartel (2000) carried out a study on the application of a self-developed simulation called "xyZET" for teaching Physics. The study revealed that simulations could be one of the tools for promoting students' understanding of Physics concepts. By implication, students will be able to retain and replicate what they have been taught because sound mastery and retention of concepts is a prerequisite for efficient learning of Physics. The findings of a study carried out by Rutten (2012) indicated that the acceptability of simulations as a training tool plays a significant role in making laboratory activities more effective when offered to students prior to the real laboratory activities. Through this, simulations have occupied an indispensable position in the classroom by promoting the teacher's repertoire in terms of teaching methods.

Spinner-Gelfars (2013) conducted a research using nursing students from diverse cultural backgrounds as sample. Spinner-Gelfars (2013) introduced high-fidelity simulation equipment and simulated patient actors with students role-playing real life characters. Spinner-Gelfars (2013) observed that students expressed interest in the 
simulated role-play activities. Students testified to the effectiveness of the simulation workstation in granting them opportunity to practice and evaluate their linguistic abilities and communication proficiency. Adams, Reid, LeMaster, McKagan, Perkins, Dubson, and Wieman (2008) found that through simulations students have selfdirected interaction with their environment. Adams et al. (2008) found that the attention level of students was high while interacting with the simulation environment of "sound waves". In addition, students were able to observe and link the changes that occur in the movements of the progressive waves due to the animated representation of the wave motion. As a result, the development of new ideas and skills steered students' entry behaviour and retention. In the same manner, a meta-analysis study aimed at identifying the effects of patient simulation in nursing education was conducted by Shin (2015). Results indicated that the intervention of simulations during lecture delivery improved students' psychomotor, affective, and cognitive domains of learning. The simulations introduced were able to offer students with reliable clinical learning situations. Students were permitted to observe, handle and experience clinical activities in a realistic and danger-free environment (Shin, 2015).

As revealed by Kollöffel and de Jong (2013), incorporating simulations to the teaching of Physics offers learners the ability to develop conceptual and factual knowledge by generating realities and descriptions, coined with practical knowledge by applying laws and equations to solve problems. Also, Tambade and Wagh (2011) observed the usefulness of computer simulations in simplifying Physics concepts in electrostatics among undergraduates. Results of the study revealed that the simulation package aided the conceptual understanding of electrostatics. Smetana and Bell (2012) examined the efficacy of computer simulations in supporting Science instruction and learning. Smetana and Bell (2012) reported that computer simulations in Science instruction are efficient instructional practices that promote science content knowledge, enhance process skills, and facilitate theoretical change. All the studies carried out on the effectiveness of computer based simulations on Physics practical class experience are foreign. The cultural background of the students as well as that of the teachers are not similar to that of Nigeria. It is therefore essential that the effect of computer based simulation Physics practical in Osun State, Nigeria be determined. This will help in making unbiased recommendations to all the stakeholders in Physics education in secondary schools in the state.

Cayvaz, Akcay and Kapici (2020) in a study to compare the effects of computer-based simulations and textbook based instructions find that simulation-based instruction was significantly more effective in middle school students' achievement than text-book based instructions. Cayvaz et al (2020) posited further that simulation-based instructions are precious tools for enhancing student's conceptual knowledge in science topics. The study further revealed that students who were taught by simulation-based instructions enhanced their inquiry skills significantly more than those taught with text-book-based instructions. It was concluded that simulations provide many advantage for enhancing students' learning and inquiry skills if they are used properly.

There are opinions on the influence of sex on the effects of computer based simulations on students' academic performance in other science subjects. Alake and Olojo (2020) in their study on Effects of Computer Simulation Package on Academic Performance of Senior Secondary School Students in Some Science Concepts in Ekiti State, Nigeria found that the use of computer simulation package (CSP) has significant effect on students' academic performance $\left(\mathrm{F}\right.$-cal $\left.=955.93 ; \mathrm{p}=0.00^{*}<0.05\right)$ while gender showed no significant influence on students' performance (F-cal 1.03, P $=0.312>0.05$ ). Oloruntoba, Sani and Kazeem (2016) also posited that although students taught with computer simulation performed better than those taught using lecture method in Chemistry, computer simulation is gender friendly. Okwuduba, Offiah and Madichie (2018) result also revealed that computer simulation was more effective in enhancing students' achievement in chemistry than lecture method and that there was no significant difference on students' achievement due to gender. Duyilemi, Olagunju and Olumide (2014) also stated that computer based simulations was found suitable for both sexes while carrying out a study on the effects of computer simulation package on students' attitude towards Biology. It is therefore necessary to find out if the use of computer based simulations in the teaching of Physics practical in Osun state, Nigeria will follow the same trend.

\subsection{Objectives of the Study}

(i) determine the effects of Computer Based Simulations (CBSs) on Students' performance in Physics Practical; determine the influence of sex on the effect of CBSs on students' performance in Physics practical.

\subsection{Research Hypotheses}

Ho1: There is no significant difference in the performance of students exposed to CBSs and the control in Physics Practical in secondary schools in Osun State

Ho2: Sex has no significant influence on the effect of CBSs on students' performance in Physics practical

\section{Methodology}

The pre-test, post-test, control group quasi experimental design was adopted for this study. The population 
comprised all Senior Secondary School Physics Students in Osun State, Nigeria. Seventy four Physics students that were in SSII class were selected using multistage sampling procedure. A senatorial district was selected from the three senatorial districts in the state using random sampling technique. One local government area was also selected from all the local government areas in the state through randomization. Two public schools were purposively selected from all the schools in the local government based on accessibility to computer systems and proximity to the base of the researcher. The two schools were randomly assigned to experimental and control. Permission was sought through Rathish Gangadharan the Senior Project Manager from Amrita Centre for Research in Analytics, Technologies and Education (Amrita CREATE), Amrita University, India for access and privilege to use olabs a computer based simulation developed by the University offline. Students in the experimental group were taught using the Computer-based Simulations (CBSs) that was downloaded from olabs. The CBSs were downloaded on computers that were available in the school computer laboratory. Students in the control group were taught using the traditional method of teaching Physics practical in the State. There were five students in a group in the control group. The students in each of the group were requested to be observing the teacher as he was conducting the experiment. The teacher followed the guidelines provided in the Physics practical workbook. The teacher after the demonstrations guided the students in carrying out the experiment. The students were to take the readings and plot the graph for the particular experiment. They were to submit their practical workbook for grading. These activities was repeated for different experiments. The procedure for data gathering lasted for six weeks. The Physics Practical Performance Test (PPPT) was used for data gathering. The PPPT was a standardized past question of senior secondary school certificate examination conducted by West Africa Examination Council (WAEC). The content validity of the instrument was determined by presenting it to 5 secondary school Physics teachers who ascertain the suitability of the instrument for the study. PPPT was used as pretest and the posttest. The students in the experimental group were exposed to the CBSs for six weeks. They were exposed to various Physics practical activities ranging from topics in Mechanics, Optics, Electricity and Heat. The posttest was administered on the students in the experimental and the control at the end of the six weeks. Data collected were analysed using ANCOVA and 2 - ways ANOVA.

\section{Results and Discussions}

3.1. Ho1: There is no significant difference in the posttest scores of Physics students exposed to the CBSs and the control.

Table 1. ANCOVA of the difference in the posttest scores of students exposed to CBSs and the control

\begin{tabular}{lcrrrr}
\hline Source & Type III sum of square & Df & Mean Square & \multicolumn{1}{c}{ F } & \multicolumn{1}{c}{ Sig. } \\
\hline Corrected Model & $2909.571^{\mathrm{a}}$ & 2 & 1454.785 & 166.579 & .000 \\
Intercept & 870.434 & 1 & 870.434 & 99.668 & .000 \\
Pretest & 1370.640 & 1 & 1370.640 & 156.944 & .000 \\
Group & 48.141 & 1 & 48.141 & 5.512 & .022 \\
Error & 620.065 & 71 & 8.733 & & \\
Total & 98858.500 & 74 & & & \\
Corrected Total & 3529.635 & 73 & & &
\end{tabular}

a. $\mathrm{R}$ Squared $=.824$ (Adjusted R Squared $=.819$ )

The analysis of the scores as presented in Table 1 showed a significant difference in the posttest score of students exposed to CBSs and the control $\left(\mathrm{F}_{(1,71)}=5.512 ; \mathrm{p}<0.05\right)$ Therefore, hypothesis 1 which states that there is no significant effect of CBSs on students' academic performance in Physics practical is rejected. The students in the experimental group have more learning gain than those in the control. The students that were exposed to CBSs performed significantly better than that of the students in the control group in Physics practical. 
3.2. Ho2: Sex has no significant influence on the effect of CBS on students' performance in Physics practical Table 2: Two - way ANOVA of test of between-subject effects of the influence of sex on the effect of CBSs on students' academic performance in Physics practical

Dependent Variable: Posttest

\begin{tabular}{lrrrrr}
\hline Source & Type III Sum of Squares & df & Mean Square & \multicolumn{1}{c}{ F } & Sig. \\
\hline Corrected Model & $1690.110^{\mathrm{a}}$ & 4 & 422.528 & 47.234 & .000 \\
Intercept & 626.089 & 1 & 626.089 & 69.991 & .000 \\
Pretest & 1327.932 & 1 & 1327.932 & 148.450 & .000 \\
Group & 89.665 & 1 & 89.665 & 10.024 & .002 \\
Sex & 2.696 & 1 & 2.696 & .301 & .585 \\
Group * Sex & .436 & 1 & .436 & .049 & .826 \\
Error & 617.228 & 69 & 8.945 & & \\
Total & 85823.500 & 74 & & & \\
Corrected Total & 2307.338 & 73 & & & \\
\hline
\end{tabular}

a. R Squared $=.732$ (Adjusted R Squared $=.717)$

2 - Way ANOVA was employed to carry out the test of between subjects effect of the influence of gender on the effect of CBSs on students' academic performance in Physics practical with pretest as covariate. The result as shown in Table 2 shows no significant difference $\left(F_{(1,74)}=0.05 ; p>0.05\right)$. Therefore the objectives which state that sex has no significant influence on the effect of CBS on students' performance in Physics practical is not rejected. This agreed with Alake and Olojo (2020), Olorunkoba, Sani and Kazeem (2016) and Duyilemi, Olagunju and Olatunde (2014).

\section{Discussion}

The findings show that the CBSs enhanced students' academic performance in Physics. The analysis of the results of the achievement test showed that the experimental group exhibited higher level of achievement and performance than the control group. Students exposed to CBSs had better performance and achievement than the control group. This finding also agrees with the findings of Hartel (2000) that simulations could promote students' understanding of Physics concepts. A study conducted by Finkelstein, Adams, Keller and LeMaster in 2005 revealed similar findings that the use of computer simulations could enhance students' manipulative skills and mastery of Physics concepts. As stated in Kayak and Buyuk (2012) attitude affects academic performance and not the other way round and also in Taibu et al (2021) that computer-based simulations positively affects students attitude to Physics, the students' academic performance in Physics practical is expected to be significantly enhanced. Any intervention that can aid students' motivation as well as attitude is expected to aid students' academic achievement.

Computer-based simulations are not gender sensitive as revealed in the study. Computer based simulations can therefore be employed in practical activities in secondary schools in Osun State since sex has no significant influence on its effect on students' achievement in Physics practical. Both genders are friendly with the use of the CBSs. Effective use of computer-based simulation will improve science process skills of students (Taibu et al, 2021; Cayvaz et al 2020) schools in Osun State should therefore consider the opportunities provided to adopt the use of CBSs in practical activities.

\section{Conclusion}

This study investigated the effect of computer-based simulations on students' academic performance in Physics practical in Osun state, Nigeria. It also determined the influence of sex on the effects of the simulations on students' academic performance. Computer-based simulations developed by Amrita University (CREATE) was adopted for the study. The simulations were used offline. The experiment took six weeks. The computer-based simulations has significant effect on students' academic performance in Physics practical. Sex has no significant influence on the effect of computer based simulations on the students' academic performance in Physics practical

\subsection{Recommendations}

(i) the use of Computer-based Simulations in the teaching of Secondary Schools Physics practical should be encouraged;

(ii) indigenous and local content developers should be trained on how to develop computer based simulations for the teaching of Physics practical locally; 
(iii) provisions should be made so that secondary school students will have quality access to computers in the schools;

(iv) conscious effort should be taking in ensuring that the digital divide between the computer haves and have nots are closed.

\subsection{Suggestions for Future Study}

The effects of the simulations on students' science process skills and engagement at Osun State secondary schools may be explored.

\section{Acknowledgements}

Special appreciation to Rathish Gangadharan the Senior Project Manager from Amrita Centre for Research in Analytics, Technologies and Education (Amrita CREATE), Amrita University, India for giving access and privilege to download and use olabs a computer based simulation developed by the University for the study. All members of staff of Amrita CREATE are acknowledged and appreciated.

\section{References}

Abungu, H. E., Okere, M. I., \& Wachanga, S. W. (2014). Effect of science process skills teaching strategy on boys and girls' achievement in chemistry in Nyando District, Kenya. Journal of Education and Practice, 5(15), $42-48$.

Adams, W. K., Reid, S., Lemaster, R., McKagan, S. B., Perkins, K. K., \& Wieman, C. E. (2008). A study of educational simulations part 1 - Engagement and learning. Journal of Interactive Learning Research, 19(3), 397-419

Adegoke, B. A., \& Chukwunenye, N. (2013). Improving students' learning outcomes in practical Physics, which is better? computer simulated experiment or hands-on experiment? IOSR Journal of Research \& Method in Education, 2(6), 18-26.

Alake, E. M. \& Olojo, J. O. (2020) Effects of computer simulation package on academic performance of senior secondary school students in some science concepts in Ekiti State. Nigeria Journal of Education, Society and Behavioural Science 33(11): 123-130

Alhassan, D. S. \& Dantani, I. W. (2013). Effects of computer assisted instructional package on junior secondary school students' achievements and retention. International Journal of Humanities and Social Science Invention 2(5) 69 - 74 Retrieved from www.ijhssi.org

Anagbogu, M. A. \& Ezeliora, B. (2007). Sex differences and scientific performance. Women Journal of Science and Technology, 4, 10-20.

Ariyo, A. O. (2006). School and student factors as determinants of students' achievement at the secondary school level in Oyo State, Nigeria. (Unpublished doctoral dissertation). University of Ibadan, Ibadan.

Arlene H. Spinner-Gelfars (2013) Using simulation to promote effective communication with a diverse student population, Teaching and Learning in Nursing, 8 (3), 96-101, ISSN 1557-3087, https://doi.org/10.1016/j.teln.2013.01.004.

(https://www.sciencedirect.com/science/article/pii/S155730871300005X)

Azar, A. \& Şengüleç, Ö.A. (2011). Computer-assisted and laboratory-assisted teaching methods in Physics teaching: The effect on student Physics achievement and attitude towards Physics. Eurasian Journal of Physics and Chemistry Education, Jan (Special Issue), 43-50.

Bajah, S. T. (1998). Stepping into science: The ELSSA way. STAN Bulletin, 15(2), 6-8.

Bichi, S. S. (2002). Effect of problem solving strategy and enriched curriculum on students' achievements in evolution concepts among secondary school students. (Unpublished doctoral thesis). Ahmadu Bello University, Zaria.

Bunkure, Y.I (2008). Effects of computer assisted instructional software on students' academic achievement in Physics. (Unpublished M.Ed. dissertation). Ahmadu Bello University Zaria.

Cayvaz, A., Akcay, H., \& Kapici, H.O. (2020). Comparison of simulation-based and textbook-based instructions on middle school students' achievement, inquiry skills and attitude. International Journal of Education in Mathematics, Science and Technology (IJEMST), 8(1), 34-43

Duyilemi, A. N., Olagunju, A. M. \& Olumide, O. J. (March, 2014) Effects of computer simulation package, gender and parental education on Nigerian secondary school students' attitude towards Biology Proceedings from 21st Century Academic Forum Conference. Harvard Boston, MA U.S.A. 1 (1), 114 - 136

Eysink, T. H. S., de Jong, T., Berthold, K., Kolloffel, B., Opfermann, M., \& Wouters, P. (2009). Learner performance in multimedia learning arrangements: An analysis across instructional approaches. American Educational Research Journal, 46(4), 1107-1149.

Federal Ministry of Education (2014). Education for All: A collection of responsibilities. Abuja: NERDC Printers. Finkelstein, N. D., Adams, W. K., Keller, C. J., Kohl, P. B., Perkins, K. K., Podolefsky, ～N. S., Reid, S.， \& 
LeMaster, R., (2005). When learning about the real world is substituting computer simulations for laboratory equipment. Education Research, 1, 010103. http://journals.aps.org/prstper/pdf/10.1103/PhysRevSTPER.1.010103

Gambari, A. I., Falode, O. C., Fagbemi, P. O. \& Idris, B. (2012). Effect of virtual laboratory strategy on the achievement of secondary school students in Nigeria. Proceedings of the 33rd Annual Convention and National Conference of Nigeria Association for Educational Media and Technology (NAEMT). Emmanuel Alayande College of Education, Oyo State.

Hartel, H. (2000). xyZET: A simulation program for Physics teaching. Journal of Science Education and Technology, 9 (3), 275- 285.

Idowu, L. (2015). Effects of computerized simulation, drill and practice, and tutorial instructional packages on learning outcomes of Osun State junior secondary school Fine-arts students. (Unpublished doctoral dissertation). Obafemi Awolowo University, Ile - Ife.

Jegede, S.A. \& Adedayo, J.O. (2013): Enriching Physics education in Nigeria towards enhancing a Sustainable Technologies Development. Greener Journal of Educational Research. 3(2) 80-84.

Kaya, H. \& Buyuk, U. (2012) Attitude towards physics lessons and physical experiments of the high school students, European Journal of Physics Education 2 (1)

Kollöffel, B., \& de Jong, T. (2013). Conceptual understanding of electrical circuits in secondary vocational engineering education: Combining traditional instruction with inquiry learning in a virtual lab. Journal of Engineering Education, 102(3), 375-393.

Kost, L. E., Pollock, S. J. \& Finkelstein, N. D. (2009). Characterizing the gender gap in introductory Physics (EJ826790). Physics education research, 5(1) 1-14.

Kozielska, M., \& Kedzierski, R., (2007). Computer simulation in learning Physics as a useful teaching method- A report of Research. The New Educational Review,83-94.

Kukkonen, J. E., Kärkkäinen, S., Dillon, P. \& Keinonen, T. (2014). The Effects of scaffolded simulation-based inquiry learning on fifth-graders' representations of the greenhouse effect. International Journal of Science Education, 36(3), 406-424.

Kuti, J.B. (2012). Effect of split attention multimedia principle and cognitive load on senior secondary school students' retention in Quantum Physics in Ogun State, Nigeria. (Unpublished doctoral dissertation), University of Ibadan, Ibadan.

Lakpini, M.A., \& Atadoga, M.M. (2012). Learning environment on senior secondary school students' academic performance in science in public secondary schools in Kaduna State. Proceedings of the 1stAfrican Forum of Teaching Regulatory Authority (AFTRA), 1, 190-196.

NERDC (2005) National Minimum Standard For Early Child Care Centres in Nigeria. Abuja, NERDC Press

Ogunleye, A. O. (2000). Towards the optimal utilization and management of resources for the effective teaching and learning of physics in schools. 41st Annual Conference Proceeding of STAN (pp. 313 - 322).

Ogunleye, A., (2001). "Address of the Chairman of Science Teachers Association of Nigeria, Lagos" at the $5^{\text {th }}$ Annual conference of Lagos State STAN, held in July 23rd-26th in Lagos State.

Okebukola, P. A. O. (1997). The state of science education in Nigeria. Paper presented at the ELLSA British Council Primary Science Forum, Kaduna, Nigeria.

Okebukola, P. A. O. (2004). Practical Handbook on Instructional Media. 2nd Edition, Graphcom Publishers, Ilorin.

Okwuduba, E. N., Offiah, F. C. \& Madichie, C. J. (2018). Effect of computer simulations on secondary school students' academic achievement in Chemistry in Anambra State Asian Journal of Education and Training 4, (4), 284-289, DOI: 10.20448/journal.522.2018.44.284.289

Olorukooba, S. B., Sani, S. \& Kazeem, S. (2016). The Impact Of Computer Simulations On Performance And Retention Of Students In Qualitative Analysis At Senior Secondary Schools In Zaria, Kaduna State $A T B U$, Journal Of Science, Technology \& Education (JOSTE); 4(2), 169 - 178

Oteyola, T. A. (2010). Application of the intelligent tutoring systems to the teaching of introductory Physics in Adeyemi College of Education, Ondo. (Unpublished M.A.Ed. dissertation). Obafemi Awolowo University, Ile-Ife.

Oteyola, T. A (2015). Effects of two intelligent tutoring packages on Physics students' processing skills and learning outcomes in selected college of education in southwestern Nigeria. (Unpublished doctoral dissertation). Obafemi Awolowo University. Ile-Ife.

Omosewo, E.O. (1999). Physics educators' perception of problems militating against effective teaching of Physics in Nigerian Secondary Schools. Journal of Educational Theory and Practice 5(1\&2) 1-11.

Romero, C. \& Martinez, E. (2012). Simulation-based teaching in a course of fluid mechanics. Proceedings of the 4Th International Conference on Education and New Learning Technologies, Barcelona, Spain.

Rutten, N., van Joolingen, W.R. \& van der Veen, J.T. (2012). The learning effects of computer simulations in science education. Computers \& Education, 58(1), 136-153. Elsevier Ltd. Retrieved May 21, 2021 from 
https://www.learntechlib.org/p/50686/.

Smetana, L. K. \& Bell, R. L. (2012). Computer simulations to support science instruction and learning: A critical review of the literature. International Journal of Science Education, 34(9), 1337-1370.

Taibu, R., Mataka, L. \& Shekoyan, V. (2021). Using PhET simulations to improve scientific skills and attitudes of community college students. International Journal of Education in Mathematics, Science, and Technology (IJEMST), 9(3), 353-370

Tambade, P., S., \& Wagh, B., G., (2011). Assessing the effectiveness of computer assisted instructions in Physics at undergraduate level. Eurasian Journal of Physics and Chemistry Education, 3(2), 127- 136. Retrieved from http://www.google.ae/url?sa=t\&rct=j\&q=\&esrc=s\&source=web\&cd=1\&ved $=0$ CB8QFjAAahUKEwiypsLqhdnIAhUBJR4KHVzjBq8\&url=http\%3A\%2F\%2F www.eurasianjournals.com\%2Findex.php $\% 2$ Fejpce $\% 2$ Farticle $\% 2$ Fdownload2F $683 \% 2$ F392\&usg=AFQjC NH5jwKVRFtGzNptWVUsZC2eew0GKg

Tsui, C.Y and Treagust, D.F. (2004). Learning genetics with multiple external representations: Preliminary findings in a laptop school. Proceedings of Western Australian Institute for Educational Research Forum.

Umeh, M. O. (2002). Reducing teachers' instructional difficulties in some content areas of some senior secondary school Biology curriculum for sustainable development. Proceedings of the 43rd annual conference of the Science Teachers Association of Nigeria.

West African Examination Council (2011-2014). Senior school certificate examinations, May/June (2011- 2014) WASSCE Chief Examiners' Reports. Yaba Lagos: WAEC publishers. 